\title{
Neuroprotective Effects of Huperzine A
}

\author{
A Natural Cholinesterase Inhibitor for the Treatment of Alzheimer's Disease
}

\author{
Rui Wang Xi Can Tang \\ State Key Laboratory of Drug Research, Shanghai Institute of Materia Medica, Shanghai Institutes for \\ Biological Sciences, Chinese Academy of Sciences, Zhangjiang Hi-Tech Park, Shanghai, China
}

\section{Key Words}

Huperzine A · Alzheimer's disease ·

Acetylcholinesterase - Cholinesterase inhibitor ·

Cognitive enhancer - Neuroprotection - Oxidative stress ·

Beta-amyloid · Amyloid precursor protein - Cerebral

ischemia - Apoptosis - Apoptotic-related gene •

Mitochondria - Glutamate $\cdot$ NMDA receptor $\cdot$ Potassium current

\begin{abstract}
Huperzine A (HupA), isolated from Chinese herb Huperzia serrata, is a potent, highly specific and reversible inhibitor of acetylcholinesterase. It has been found to reverse or attenuate cognitive deficits in a broad range of animal models. Clinical trials in China have demonstrated that HupA significantly relieves memory deficits in aged subjects, patients with benign senescent forgetfulness, Alzheimer's disease (AD) and vascular dementia (VD), with minimal peripheral cholinergic side effects compared with other AChEls in use. HupA possesses the ability to protect cells against hydrogen peroxide, $\beta$-amyloid protein (or peptide), glutamate, ischemia and staurosporine-induced cytotoxicity and apoptosis. These protective effects are related to its ability to attenuate oxidative stress, regulate the expression of apoptotic proteins Bcl-2, Bax, P53 and caspase-3, protect mito-
\end{abstract}

chondria, and interfere with APP metabolism. Antagonizing effects on NMDA receptors and potassium currents may contribute to the neuroprotection as well. It is also possible that the non-catalytic function of AChE is involved in neuroprotective effects of HupA. The therapeutic effects of HupA on AD or VD are probably exerted via a multi-target mechanism.

Copyright $\odot$ 2005 S. Karger AG, Base

Alzheimer's disease (AD) is a progressive, neurodegenerative disorder associated with a global impairment of higher mental function, and presenting an impairment of memory as the cardinal symptom [1]. Histopathological hallmarks of the disease are the extracellular deposition of amyloid $\beta$-peptide $(\mathrm{A} \beta)$ in senile plaques, the appearance of intracellular neurofibrillary tangles (NFT), a loss of cholinergic neurons, and extensive synaptic changes in the cerebral cortex, hippocampus and other areas of brain essential for cognitive functions.

To date, the cause and the mechanism by which neurons die in $\mathrm{AD}$ remain unclear, but $\mathrm{A} \beta$ has been established as a crucial factor in AD pathogenesis. A $\beta$ deposition may cause neuronal death via a number of possible mechanisms, including oxidative stress, excitotoxicity, energy depletion, inflammation and apoptosis. Despite this multifactorial etiology, genetics plays a key role in

\section{KARGER}

$\mathrm{Fax}+41613061234$ E-Mail karger@karger.ch www. karger.com (c) 2005 S. Karger AG, Base

1424-862X/05/0142-0071 \$22.00/0

Accessible online at:

www. karger.com/nsg
Prof. Xi Can Tang, State Key Laboratory of Drug Research

Shanghai Institute of Materia Medica, Shanghai Institutes for Biological Sciences Chinese Academy of Sciences, $555 \mathrm{Zu}$ Chong Zhi Road

Zhangjiang Hi-Tech Park, Shanghai 201203 (China)

Tel. +86215080 6710, Fax +86215080 7088, E-Mail xctang@mail.shcnc.ac.cn 
disease progression. However, environmental factors (e.g. cytokines, neurotoxins) may be even more important in the development and progression of AD. Several lines of evidence support the involvement of oxidative stress [2, 40]. Oxidative damage, mediated by reactive oxygen species (ROS) generated following cell lysis, oxidative bursts, or an excess of free transition metals, has been hypothesized to play a pivotal role in $\mathrm{AD}$ neurodegeneration. On the other hand, postmortem studies provide direct morphological and biochemical evidence that some neurons in the $\mathrm{AD}$ brain degenerate via an apoptotic mechanism $[30,51]$, which may or may not be linked to ROS. The biological mechanism underlying the formation of $\mathrm{AD}$ is clearly complex, with many factors contributing to the neuropathology. Thus it is not surprising that a number of different intervention therapies are currently being researched to address distinct aspects of the disease.

Huperzine A (HupA) is a novel Lycopodium alkaloid with recognized medicinal properties. In China the folk medicine Huperzia serrata (Qian Ceng Ta) (fig. 1), a source of HupA, has been used for centuries in the treatment of contusions, strains, swelling, schizophrenia, etc. The active principle, HupA, is a potent, reversible, and selective inhibitor of acetylcholinesterase (AChE) [56]. Its potency in $\mathrm{AChE}$ inhibition is similar or superior to that of physostigmine, galanthamine, donepezil and tacrine $[60,67]$. AChE exists in multiple molecular forms that can be distinguished by their subunit associations and hydrodynamic properties [6, 41]. In mammalian brain, the bulk of AChE occurs as a tetrameric, G4 form (10S) together with much smaller amounts of a monomeric, G1 (4S) form $[4,22]$. This phenomenon led us to investigate the possibility of HupA on differential inhibition of AChE forms [93]. We observed that HupA preferentially inhibited tetrameric $\mathrm{AChE}$ ( $\mathrm{G} 4$ form), while tacrine and rivastigmine preferentially inhibited monomeric AChE (G1 form). Donepezil showed pronounced selectivity for G1 AChE in striatum and hippocampus, but not in cortex. Physostigmine showed no form-selectivity in any brain region [93].

HupA has been found to reverse or attenuate cognitive deficits in a broad range of animal models. Enhancement of learning and memory performance was documented in the passive footshock avoidance paradigm [37, 54, 98, 99], the classic water maze escape task [36, 79], and spatial discrimination in the radial arm maze [72]. Similarly, cognition enhancement was found in a delayed-response task in aged monkeys [78] and in reserpine- or yohimbinetreated monkeys [44]. Beneficial effects were seen not only in intact adult rodents, but also in rodents cognitive- ly impaired by age $[37,79]$ or by treatment with scopolamine [16, 23, 36, 54, 59, 65, 98], AF64A [73, 9], electroshock [59, 99], cycloheximide [99], $\mathrm{NaNO}_{2}$ [99], or $\mathrm{CO}_{2}$ $[37,98]$. In addition, HupA improved cognition in cholinergically lesioned rats [37, 99], and it reduced the spatial working memory deficit induced by lesion of the nucleus basalis magnocellularis [74]. These effects are attributable to increased synaptic ACh. Early on, HupA was found to cause a significant increase in ACh level in rat brain [55, 100]. More recently, a rise in cortical ACh levels has been demonstrated by microdialysis in awake, free-moving rats. In this study HupA was 8- and 2-fold more potent than donepezil and rivastigmine, respectively, and its effect was longer lasting [34].

Clinical trials of HupA in China have demonstrated a meaningful improvement in the memory of aged subjects, individuals with benign senescent forgetfulness and patients with AD. The results indicate minimal peripheral cholinergic side effects compared to other AChEIs in use; even more important, HupA lacks the dose-limiting hepatotoxicity induced by tacrine $[75-77,84,90]$. Adverse effects in the clinical trials were reported at a very low rate and are mainly cholinergic. Examples are dizziness, nausea, gastroenteric symptoms, headaches and depressed heart rate. Several clinical trials have addressed the effects of HupA on vascular dementia (VD). VD is currently considered to be the second most common form of dementia in Europe and the USA. However, in Asia and many developing countries including China, the incidence of VD exceeds that of AD. Multicenter, randomized, double-blind, placebo-controlled clinical trials in China proved that HupA markedly improved the cognitive function of VD [32, 38, 39, 90]. This article will summarize and discuss current research focused on elucidating the neuroprotective effect of HupA.

\section{Protection of HupA against Hydrogen Peroxide and $\beta$-Amyloid Protein-Induced Injury by Attenuating Oxidative Stress}

Several neurodegenerative disorders such as AD, cerebral ischemia-reperfusion and head injury are thought to be related to changes in oxidative metabolism. Increased oxidative stress, resulting from free radical damage to cellular function, can be involved in the events leading to $\mathrm{AD}$, and is also connected with lesions called tangles and plaques. Plaques are caused by the deposition of $A \beta$ and are observed in the brains of AD patients [7, 40, 45, 48]. Studies show that oxygen radicals initiate amyloid build- 

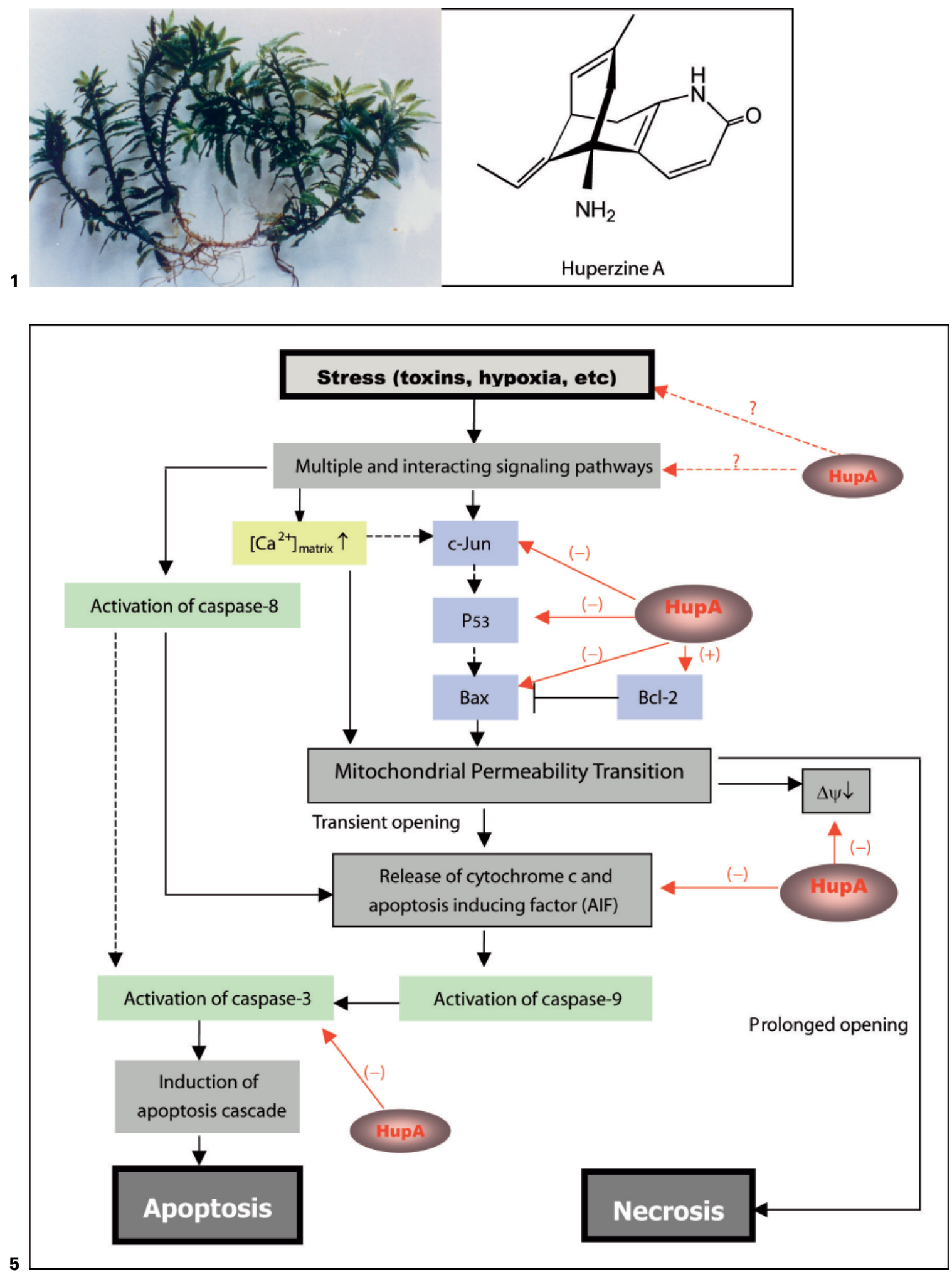

Fig. 1. Chinese herb Huperzia serrata (Qian Ceng Ta).

Fig. 5. Anti-apoptotic mechanism of HupA. Black real line arrows = apoptotic-inducing pathway; red real line arrows $=$ affecting sites of HupA; red dash arrows $=$ speculative pathways; $(-)=$ inhibiting; $(+)=$ promoting. 


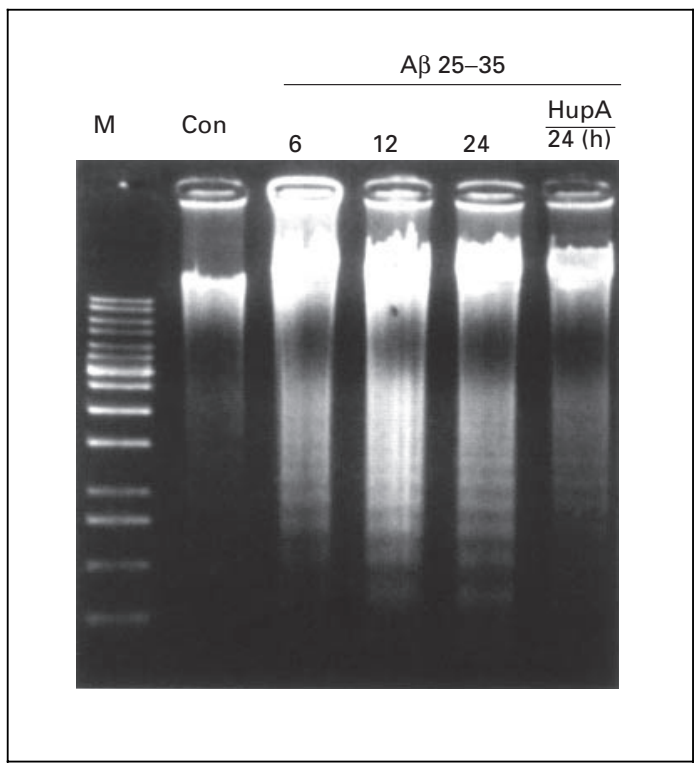

Fig. 2. Reduction of $A \beta 25-35$-induced DNA fragmentation by HupA. Neurons were treated with $20 \mu M$ of A $\beta 25-35$ with or without $1 \mu M$ of HupA. Fragmented DNA was isolated by NucleoBond DNA and RNA purification kit, electrophoresed with agarose gel, and finally stained with ethidium bromide. $\mathrm{M}=\mathrm{DNA}$ size marker; Con $=$ control .

up leading to neurodegeneration [19]. HupA has been found to protect against $\mathrm{H}_{2} \mathrm{O}_{2}$ and $\mathrm{A} \beta$-induced cell lesion, to decrease the level of lipid peroxidation, and to increase antioxidant enzyme activities in rat PC12 and primary cultured cortical neurons [68-70]. Following a 6-hour exposure of the cells to $\mathrm{H}_{2} \mathrm{O}_{2}(200 \mu M)$ or a 48-hour exposure of the cells to $\mathrm{A} \beta 25-35(1 \mu M)$, a marked reduction in cell survival and the activities of glutathione peroxidase (GSH-Px) and catalase (CAT) was observed, along with an increased production of malondialdehyde (MDA). Pretreatment of the cells with HupA $(0.1-10 \mu M)$ $2 \mathrm{~h}$ before $\mathrm{H}_{2} \mathrm{O}_{2}$ and $\mathrm{A} \beta$ exposure caused a significant increase in cell survival. HupA also partly reversed the $\mathrm{H}_{2} \mathrm{O}_{2-}$ and $\mathrm{A} \beta$-induced decrease of GSH-Px and CAT activity, as well as the increase in production of MDA and SOD. All these effects indicate a neuroprotective action.

The protective effect of HupA on $A \beta$-induced cell lesion was also observed in NG108-15 cells [86] and primary cultured cortical neurons [71]. In addition to elevating cell survival and GSH-Px and CAT activities while decreasing the level of MDA [70], HupA $(0.1-10 \mu M)$ significantly reduced $A \beta 25-35$-induced the formation of reactive oxygen species (ROS) in rat primary cultured cortical neurons [71].
In rat studies, an intracerebroventricular (i.c.v.) infusion of $\beta$-amyloid $1-40(800 \mathrm{pmol} \times 3)$ induced a significant cognitive deficit, morphologic signs of injury and a decrease of cortical choline acetyltransferase activity [64]. Daily i.p. administration of HupA for 12 consecutive days produced partial reversal of the $\beta$-amyloid-induced deficit in learning a water maze task. This treatment ameliorated the loss of choline acetyltransferase activity in cerebral cortex and the neuronal degeneration induced by $\beta$-amyloid 1-40 [64]. HupA also reduced the level of lipid peroxidation and superoxide dismutase in the hippocampus, cerebral cortex and serum of aged rats [49]. In a rat model of chronic cerebral hypo-perfusion, HupA significantly reduced the increases in SOD and lipid peroxide while restoring lactate and glucose to their normal levels [61]. A clinical study also demonstrated a reduction of oxygen free radicals in plasma and erythrocytes from $\mathrm{AD}$ patients [77]. These findings indicate that HupA has protective effects against free radical and $A \beta$-induced cell toxicity, which might be beneficial in the treatment of patients with various kinds of dementia.

Experience with HupA enantiomers has shown that the neuroprotective properties have no relation to anticholinesterase potency. Thus, preincubation with $(+)-$ HupA or (-)-HupA $(0.1-10 \mu M)$ protected cells with similar potency against $\mathrm{A} \beta$ toxicity and similar enhancement of survival [86]. This result contrasted with the stereoselectivity of cholinesterase inhibition in vitro and in vivo, in which (-)-HupA is approximately 50 -fold more potent than (+)-HupA. In another study, we examined drug effects on the apoptosis induced by incubation with A $325-35$ and on the increase of AChE activity accompanying this reaction. We observed that inhibiting the hydrolyzing activity of AChE without decreasing AChE expression itself did not attenuate the $A \beta 25-35$ induced apoptosis [85]. In other words, the ability of HupA to block the catalytic activity of AChE did not parallel its neuroprotective effect. Therefore, the cytoprotective effect of HupA enantiomers may relate to some kind of noncatalytic actions on AChE, or to actions on other cellular targets.

\section{Anti-Apoptotic Effect of HupA}

Apoptosis is the process by which neurons die during normal development and is also a feature of chronic and acute neurodegenerative diseases and stroke [82]. The cellular commitment to apoptosis is regulated by the $\mathrm{Bcl}-2$ family of proteins. High levels of $\mathrm{Bcl}-2$ expression will 
Fig. 3. Effects of HupA on $\mathrm{H}_{2} \mathrm{O}_{2}$-induced expression of bcl-2, bax and p53 in $\mathrm{PC} 12$ cells by RT-PCR. Cells were exposed to $100 \mu M \mathrm{H}_{2} \mathrm{O}_{2}$, and total RNA was extracted after the indicated recovery period and then subjected to RT-PCR. The PCR products were normalized by $\beta$-actin mRNA. Lane 1 : non-treated intact control; lanes 2-5: 0, 2, 6 and $12 \mathrm{~h}$ after 30 min $\mathrm{H}_{2} \mathrm{O}_{2}$-treatment, respectively. Lanes 6-9 represent the same time points as lanes $2-5$ but preincubated with $1 \mu M$ HupA before $\mathrm{H}_{2} \mathrm{O}_{2}$ exposure.

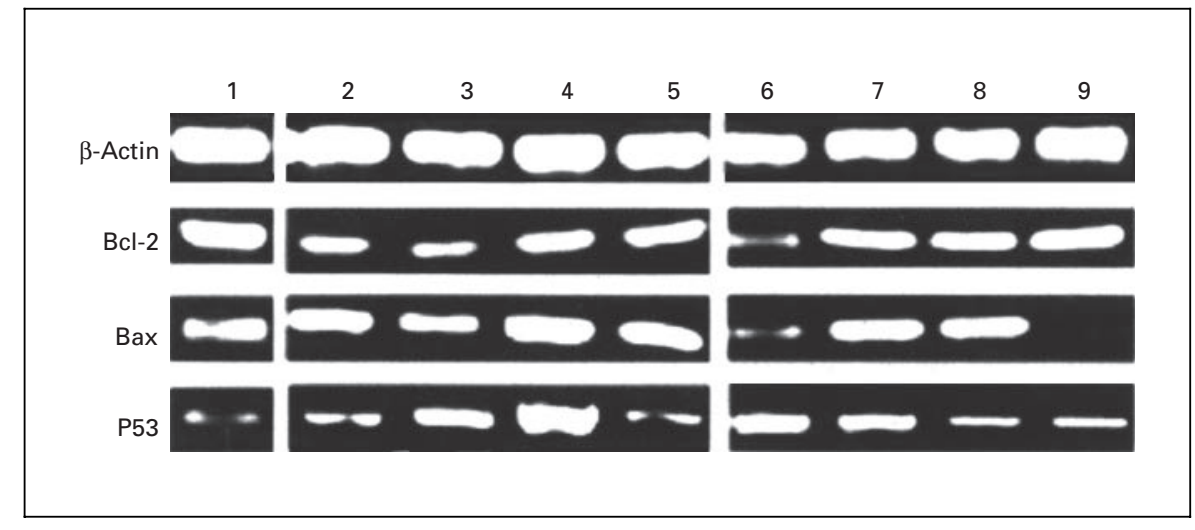

inhibit apoptosis. In contrast, an increased expression of P53 and Bax is associated with the initiation of apoptosis [29]. In accordance with previous reports, studies from our lab demonstrate typical apoptotic changes when neuron-like cells are exposed to stressors such as $\mathrm{H}_{2} \mathrm{O}_{2}, \mathrm{~A} \beta$ peptide, oxygen-glucose deprivation (OGD), serum deprivation, or the $\mathrm{PKC}$ inhibitor, staurosporine. These changes include DNA laddering, cell shrinkage, the generation of nuclear apoptotic bodies, TUNEL positive staining, and other classic hallmarks of apoptosis (fig. 2) [63, $71,87,94]$. Such abnormalities are markedly relieved by HupA. For example, in rats that received i.c.v. injections of $\beta$-amyloid1-40 (800 pmol $\times 3)$, administration of HupA $(0.1,0.2 \mathrm{mg} / \mathrm{kg}$, i.p.) for 12 consecutive days gave substantial neuroprotection in the brain. This treatment greatly reduced the number of apoptotic-like neurons and partly reversed the down-regulation of Bcl-2 and up-regulation of Bax and P53. Anti-apoptotic effects of HupA were also found in primary cultured neurons. Preincubation with HupA at concentrations higher than $0.01 \mu M$ led to a large, dose-dependent attenuation of cell toxicity induced by A $325-35(20 \mu M)$. Moreover, HupA $(1 \mu M)$ caused large reductions in the amounts of subdiploid DNA detected in a flow cytometry assay and weakened the ladder pattern on agarose gel electrophoresis, typically seen after exposure to $A \beta$ (fig. 2).

The anti-apoptotic actions of HupA may involve inhibition of the production or the effects of ROS [71]. We found that preincubation of PC12 cells with HupA before exposure to $\mathrm{H}_{2} \mathrm{O}_{2}$ substantially reduced apoptosis, by any of several measures. The same treatment also attenuated $\mathrm{H}_{2} \mathrm{O}_{2}$-induced overexpression of bax and p53, while restoring bcl-2 to normal levels (fig. 3) [63]. HupA was also effective in the OGD paradigm. Exposure to OGD for $3 \mathrm{~h}$ followed by reoxygenation for $24 \mathrm{~h}$ triggers apoptosis characterized by chromatin condensation, nucleus fragmentation and DNA laddering, accompanied by altered levels of mRNA for c-jun, p53, bcl-2 and bax. In this model, HupA significantly attenuated apoptosis and reduced the up-regulation of c-jun and bax as well as the downregulation of bcl-2 [94].

In the mitochondrial-mediated cell death pathway, a key step is transient opening of the mitochondrial permeability transition (MPT), involving a non-specific increase in the permeability of the inner mitochondrial membrane $[25,28,53]$. In this process, cytochrome $\mathrm{c}$ moves from the intermembrane space into the cytoplasm [5] where it binds to another factor (Apaf-1). In the presence of dATP, this complex polymerizes into an oligomer known as the apoptosome. The apoptosome activates the protease, caspase-9, which in turn activates caspase-3. The cascade of proteolytic reactions also activates DNAases, which leads to cell death [83].

When PC12 cells were pre-incubated with HupA at concentrations above $0.01 \mu M$, there was a marked neuroprotection against apoptosis induced by $\beta$-amyloid, with a significant reduction in mitochondrial swelling and an improvement in mitochondrial membrane potentials [unpubl. data of this lab]. Pretreatment of rat cortical neurons with HupA $(0.01-10 \mu M)$ significantly elevated cell survival and reduced all signs of apoptosis resulting from exposure to $A \beta 25-35$.

Further studies focused on caspase activation in primary cultures of rat cortical neurons subjected to a variety of stresses. Measurements of caspase-3-like fluorogenic cleavage demonstrated that HupA $(1 \mu M)$ attenuated an A $325-35$-induced increase in caspase- 3 activity at 6,12 , 24 , and $48 \mathrm{~h} \mathrm{[71].} \mathrm{Western} \mathrm{blot} \mathrm{analyses} \mathrm{confirmed} \mathrm{these}$ results at the protein level. HupA also inhibited caspase-3 activation in models of apoptosis by serum deprivation 


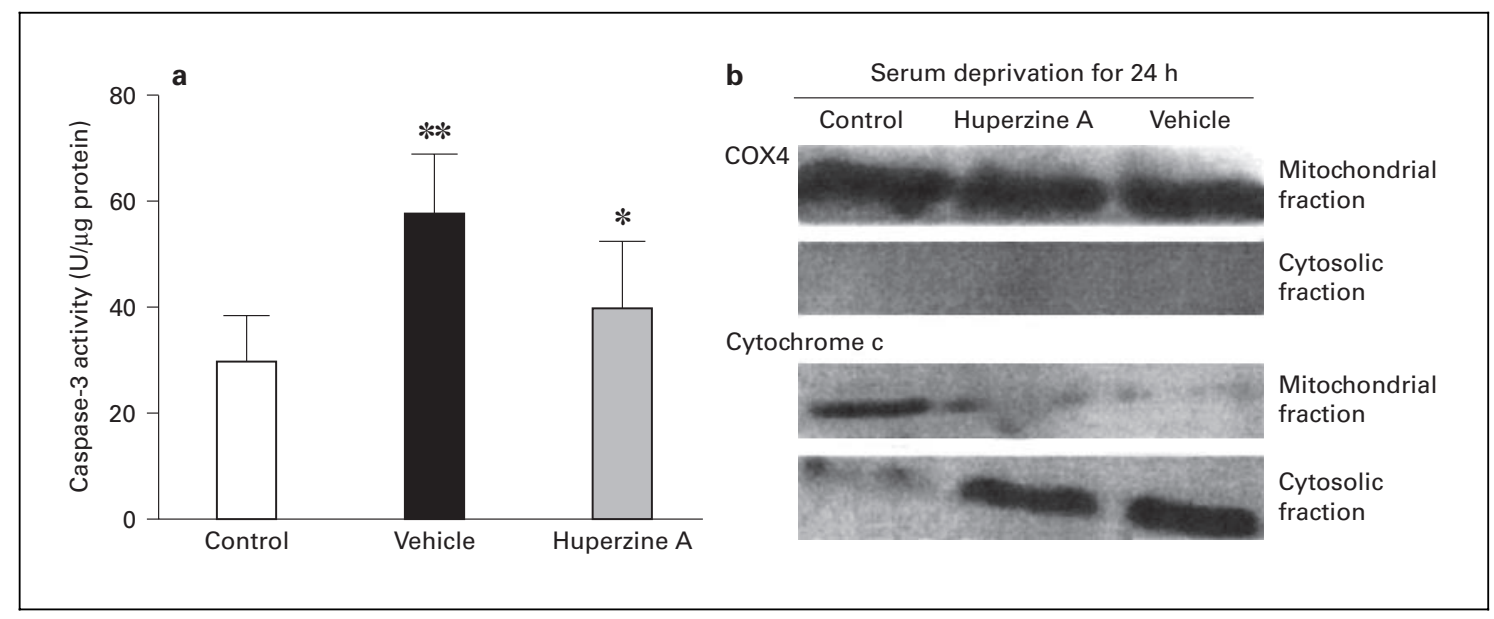

Fig. 4. Effect of HupA on caspase- 3 activity (a) and Western blot detection of cytochrome $\mathrm{c}$ and $\mathrm{COX} 4(\mathbf{b})$ in primary cortical neurons. Neurons under serum deprivation for $24 \mathrm{~h}$. HupA at a concentration of $1 \mu M$ added to the culture $2 \mathrm{~h}$ in advance. a Data expressed as means $\pm \mathrm{SD}$. Statistical comparison was made using ANOVA followed by Duncan's test. There was a significant difference between the serum deprivation group and the untreated control group. ${ }^{\# \#} \mathrm{p}<$ 0.01 compared to control group. ${ }^{*} \mathrm{p}<0.05$ compared to serum depri- vation group. b The mitochondrial and cytosolic fractions were isolated using an ApoAlert cell fractionation kit. They were then processed using the standard Western blot procedure on 12\% SDSPAGE and probe with COX4 antibody $(\sim 17 \mathrm{kDa})$ or cytochrome $\mathrm{c}$ antibody $(\sim 15 \mathrm{kDa})$. The presence of cytochrome $\mathrm{c}$ in the cytosolic fraction after induction indicates that apoptosis involves mitochondrial release of cytochrome $\mathrm{c}$ to the cytosol. and staurosporine treatment. The apoptosis induced by $24 \mathrm{~h}$ of serum deprivation was accompanied by enhanced caspase- 3 activity and a release of mitochondrial cytochrome $\mathrm{c}$ into the cytosol [97]. HupA $(0.1-10 \mu M)$ improved neuronal survival in this model, inhibiting the rise in caspase-3 activity and protein expression [97]. Likewise, cell survival was greatly enhanced when HupA (0.1$100 \mu M$ ) was introduced $2 \mathrm{~h}$ before a 24 -hour exposure to $0.5 \mu M$ staurosporine. Incubation with HupA at dose of $1 \mu M$ also reduced staurosporine-induced DNA fragmentation, up-regulation of the pro-apoptotic gene, bax, downregulation of the anti-apoptotic gene, bcl-2, and decrease in caspase-3 proenzyme protein level (fig. 4) [87].

A potassium channel with delayed rectifier characteristics may play an important role in A $\beta$-mediated toxicity. The up-regulation of an outward $\mathrm{K}^{+}$current known as $I_{k}$ mediates several forms of neuronal apoptosis and could contribute to the pathogenesis of $A \beta$-induced neuronal death. Exposure to a 20- $\mu M$ concentration of $A \beta 25-35$ or $\mathrm{A} \beta 1-42$ is known to enhance the apoptosis-related current, $I_{k}$ [81]. Interestingly, HupA will reversibly inhibit the fast transient current, $I_{\mathrm{A}}$, and the sustained potassium current, $I_{k}$, in CA1 pyramidal neurons acutely dissociated from rat hippocampus [33]. Such effects might contribute to this agent's anti-apoptotic effect.
In light of these findings and the effects of HupA on apoptosis-related genes, we propose that HupA blocks apoptosis by antagonizing the mitochondrial-dependent caspase pathway, directly or indirectly (fig. 5). The effects of HupA on the intrinsic caspase-3 pathway might be downstream consequences of altered expression of bcl-2 family genes. Functionally, bcl-2 is a potent cell death suppressor, whose over-expression can prevent cell death in response to a variety of stimuli. It is well known that Bcl-2 suppresses apoptosis by inhibiting cytochrome c release from the mitochondria. On the other hand, bax is a death-promoting factor, whose translocation to the mitochondrial membrane leads to a loss of mitochondrial membrane potential and increases mitochondrial permeability. Increased mitochondrial permeability results in the release of cytochrome $\mathrm{c}$ followed by activation of caspase-3 [21]. We consider it likely that HupA owes some of its anti-apoptotic effects to an effective antagonism of the up-regulation of bax and the down-regulation of bcl-2, which impairs mitochondria-dependent caspase pathway. At present, however, direct effects of HupA on cytochrome $\mathrm{c}$ and caspase- 3 and other possible targets are not excluded. 


\section{Effects of HupA on Secretory Amyloid Precursor Protein and Protein Kinase C-a}

$A \beta$ is a self-aggregating $39-43$-amino acid peptide that originates from a larger polypeptide termed Alzheimer's amyloid precursor protein (APP). Alternate pathways for APP processing have been described: the non-amyloidogenic secretory pathway, which releases a soluble ectodomain (APPs) and prevents $A \beta$ formation [15], and the endosomal-lysosomal pathway, which produces amyloidogenic products [24]. The amyloid hypothesis of $\mathrm{AD}[17$, $46]$ is focused on the potential toxic role of an excessive production of $A \beta$ and suggests that the aberrant metabolism of APP is a central pathogenetic mechanism for the disease.

Several factors can affect the secretory non-amyloidogenic pathway of APP. For example, the stimulation of phospholipase C (PLC)-coupled receptors, such as muscarinic $\mathrm{m} 1$ and $\mathrm{m} 3$, has been shown to potentiate the secretion of APP in cell cultures. These effects are probably mediated mainly by protein kinase C (PKC) [43]. It has also been reported that several anticholinesterases affect APP processing in addition to the catalytic function of AChE $[18,42]$.

Our own studies showed that HupA could alter APP processing in the brains of rats given i.c.v. infusions of $A \beta 1-40$, and in otherwise untreated human embryonic kidney 293 (HEK293sw) cells [88]. In the A $\beta$ treated rats, levels of APPs and PKC $\alpha$ were significantly decreased by treatment with A $\beta 1-40$. These decreases were much reduced by 12 consecutive days of HupA treatment $(0.2 \mathrm{mg} /$ $\mathrm{kg}$, i.p.), but HupA in normal rats caused no change in either APPs or PKC $\alpha$. In normal HEK293sw cells, on the other hand, the levels of APPs and PKC $\alpha$ rose progressively during an 18-hour exposure to HupA $(1 \mu M)$. However, no significant alternations in the levels of PKC $\delta$ and PKC $\varepsilon$ were found after HupA treatment. Taken together these findings suggest that HupA may affect the processing of APP by up-regulating PKC, especially PKC $\alpha$.

In an attempt to clarify the receptor mechanisms involved in such effects, we treated HEK293wt cells with cholinergic receptor antagonists [unpubl. data]. The nonselective muscarinic antagonist, scopolamine, partly blocked the HupA-induced rise in levels of APPs and PKC $\alpha$. By contrast the nicotinic antagonist, mecamylamine, had little effect. These results suggest that muscarinic $\mathrm{ACh}$ receptors may mediate, at least in part, the effects of HupA on the regulation of APPs and PKCa in HEK293sw cells.
Our recent results provide the first demonstration that HupA can reduce the disturbance of PKC and APPs both in rats and in an isolated cell line. The effect of HupA to enhance non-amyloidogenic processing of APP and elevate APPs levels likely depends on the activation of muscarinic receptors and the PLC/PKC cascade. A number of biological activities such as cell proliferation, promotion of cell-substratum adhesion, neurite outgrowth and the prevention of intracellular calcium accumulation and cell death have been attributed to APPs [47]. Since PKC is a key enzyme in signal transduction, and since APPs itself has neuroprotective effects, modulating the levels of these two proteins by HupA may well be beneficial in AD therapy (fig. 6).

\section{Protection of HupA against Hypoxic-Ischemic and Glutamate Induced Brain Injury and Cytotoxicity}

Apart from AD, the most common dementia in the elderly is VD. This disorder, like AD, presents a clinical syndrome of intellectual decline produced by ischemia, hypoxia, or hemorrhagic brain lesion. Cerebral ischemia in rats with permanent bilateral ligation of the common carotid arteries (CCA) provides a useful model of VD, in which to investigate the effects of HupA. These animals experience a significant reduction of cerebral blood flow and exhibit learning and memory impairments and neuronal damage resembling those in VD. Daily oral administration of HupA $(0.1 \mathrm{mg} / \mathrm{kg})$ to such rats for 14 days produced significant improvement in the learning of a water maze task. Simultaneously there was marked recovery from the decrease in choline acetyltransferase activity in hippocampus and a restoration of SOD, lipid peroxide, lactate and glucose to normal levels [61]. Similar protection was also observed in gerbils given subchronic oral doses of HupA $(0.1 \mathrm{mg} / \mathrm{kg}$, twice daily for 14 days) following $5 \mathrm{~min}$ of global ischemia [96].

An in vitro model of neuronal ischemia is the rat pheochromocytoma PC12 cell treated with OGD for $30 \mathrm{~min}$. In our hands, this treatment causes death in more than $50 \%$ of the cells in culture, along with major changes in morphology and biochemistry, including elevated levels of lipid peroxide, SOD activity and lactate. Cells pretreated for $2 \mathrm{~h}$ with HupA $(0.1,1$ and $10 \mu M)$, however, showed increased survival and reduced biochemical and morphologic signs of toxicity. HupA protected PC12 cells against OGD-induced toxicity, most likely by alleviating disturbances of oxidative and energy metabolism [95]. 


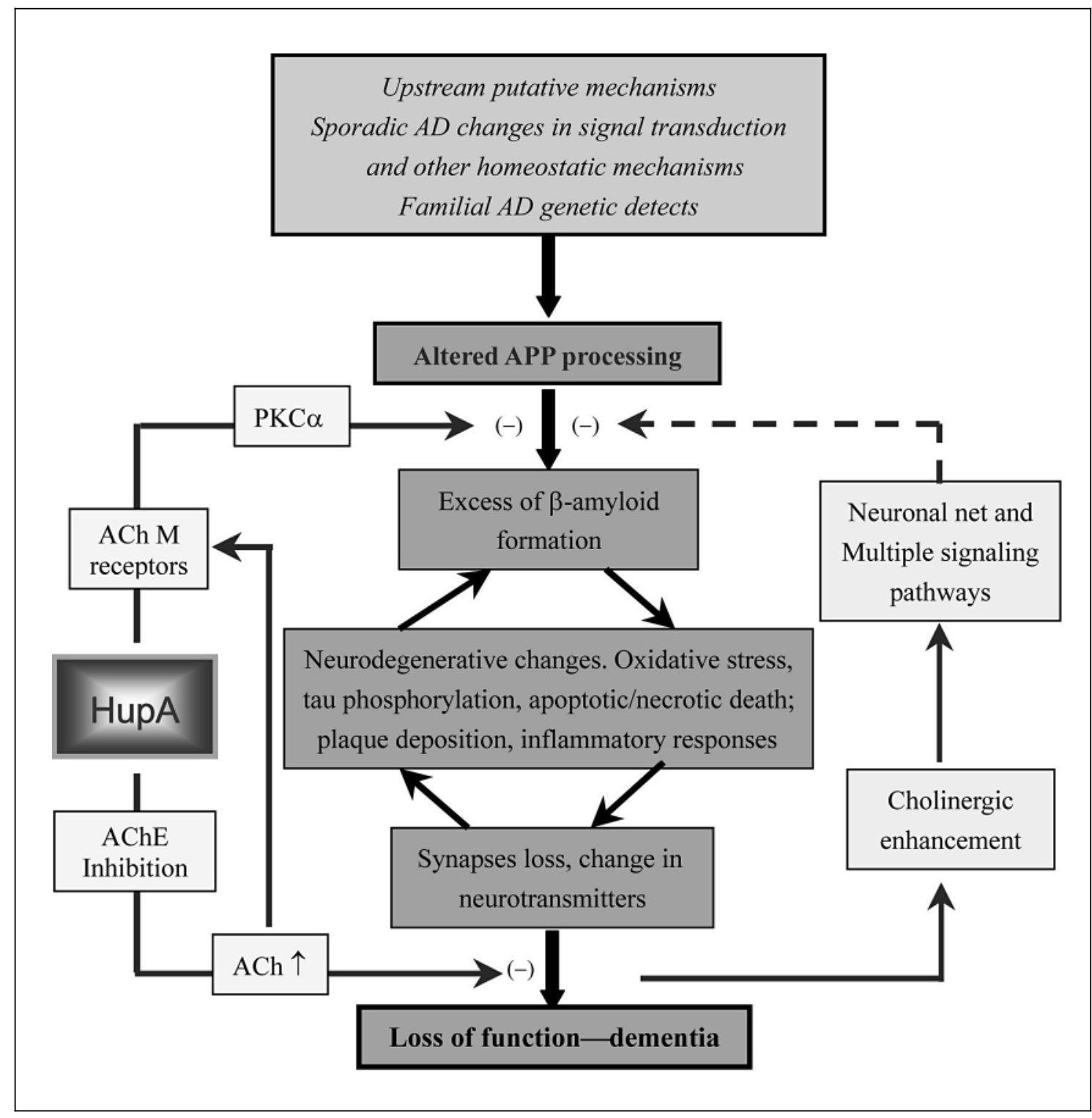

Fig. 6. Protective effects of HupA through affecting APP metabolism. Black arrows show the process of AD. Blue real line arrows show the proved pathway; blue dash arrow represents speculative pathway; (-) means reducing or inhibiting.

These findings suggested that HupA might be beneficial for VD therapy through its effects on the cholinergic system, the oxygen free radical system and energy metabolism.

A protective effect of HupA on hypoxic-ischemic (HI) brain injury has also been found in neonatal rats [62]. A unilateral $\mathrm{HI}$ brain injury was produced in 7-day-old rat pups by the ligation of the left CCA followed by $1 \mathrm{~h}$ hypoxia with $7.7 \%$ oxygen. After 5 weeks, the HI brain injury in these pups caused working memory impairments in water maze performance, as shown by an increased escape latency and a reduced time spent in the target quadrant. The combination of CCA ligation and exposure to a hypoxic environment also led to morphologic damage in the ipsilateral striatum, cortex, and also hippocampus, where it produced $12 \%$ neuronal loss in the CA1 region. Treatment with HupA at a dose of $0.1 \mathrm{mg} / \mathrm{kg}$ conferred significant protection against the behavioral and morphologic consequences of HI injury (fig. 7). The same treatment spared a significant fraction of the CA1 neurons relative 


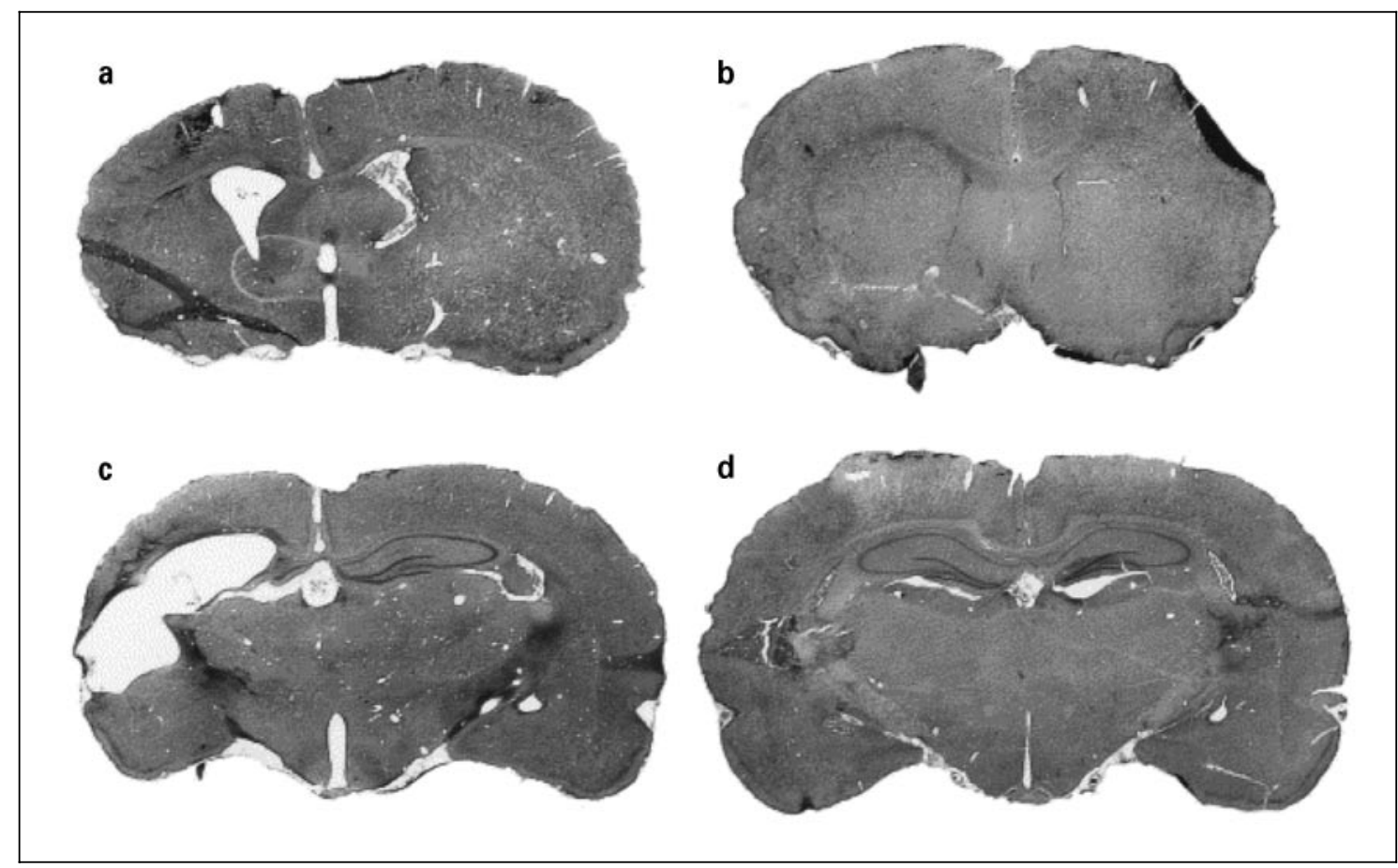

Fig. 7. Photomicrographs of coronal brain sections stained with cresyl violet at the levels of the striatum (a, b) and the dorsal hippocampus (c, d) for representative saline-treated and huperzine A $0.1 \mathrm{mg} / \mathrm{kg}$-treated rats. Intraperitoneal administration of huperzine A or saline for 5 weeks after hypoxic-ischemic (HI) brain injury in neonatal rats. Note the gross infarction and atrophy in left hemisphere of saline-treated HI rats $(\mathbf{a}, \mathbf{c})(\mathrm{n}=11)$ and the subtle reduction in the left hemisphere in huperzine A-treated HI rats $(\mathbf{b}, \mathbf{d})(\mathrm{n}=12)$.

to saline-treated HI group. These results raise the possibility that HupA have potential utility in treating $\mathrm{HI}$ encephalopathy in neonates.

Glutamate is the main excitatory neurotransmitter in the CNS, with important roles in neurotransmission and functional plasticity. Excitatory amino acid neurotransmitters are also involved in CNS pathology. The deleterious effects of overstimulation with excitatory amino acids have been implicated in a variety of acute and chronic neurodegenerative disorders such as ischemic brain damage, $\mathrm{AD}$ and neuronal cell death [11] [for reviews, see 13, 14, 26, 27, 35]. Glutamate-mediated overactivation of receptors induces excessive $\mathrm{Ca}^{2+}$ influx, which results in elevated intracellular $\mathrm{Ca}^{2+}$ concentrations $[10,12]$ with serious consequences such as necrosis and apoptosis [31]. Blockade of glutamate receptors prevents most of the $\mathrm{Ca}^{2+}$ influx and neuronal cell death induced by glutamate exposure $[50,57]$.

It has been reported that HupA protects against glutamate-induced toxicity. HupA $(100 \mu M)$ decreased neuronal cell death caused by a toxic level of glutamate (also
$100 \mu M)$. In those experiments, HupA reduced glutamate-induced calcium mobilization but did not affect the increase in intracellular free calcium induced by exposure to high $\mathrm{KCl}$ or a calcium activator Bay-K-8644 [58]. HupA dose-dependently inhibited the NMDA-induced toxicity in primary neuronal cells, most likely by blocking NMDA ion channels and the subsequent $\mathrm{Ca}^{2+}$ mobilization at or near the PCP and MK-801 ligand sites [20]. Wang et al. [66] reported that HupA reversibly inhibited NMDA-induced current in acutely dissociated rat hippocampal pyramidal neurons and blocked specific $\left[{ }^{3} \mathrm{H}\right] \mathrm{MK}-$ 801 binding in synaptic membranes from rat cerebral cortex. Of all the AChE inhibitors tested, HupA is the most powerful both in protecting mature neurons and in blocking the binding of $\left[{ }^{3} \mathrm{H}\right] \mathrm{MK}-801$. Studies on the mechanism of receptor inhibition showed that HupA reversibly inhibited NMDA-induced currents. The effect was noncompetitive, and showed neither 'voltage-dependency', nor 'use-dependency' [89]. Studies of [ $\left.{ }^{3} \mathrm{H}\right] \mathrm{MK}-801$ binding in cortex membranes suggest that HupA acts as a noncompetitive antagonist of the NMDA receptors, via a 
competitive interaction with one of the polyamine binding sites [92]. Of interest, natural (-)-HupA and synthetic (+)-HupA reduced the binding of $\left[{ }^{3} \mathrm{H}\right] \mathrm{MK}-801$ with similar potencies [91] indicating that HupA inhibits NMDA receptors in rat cerebral cortex without stereoselectivity. This result is in dramatic contrast with the stereoselective inhibition of acetylcholinesterase.

NMDA-receptor activation also mediates the generation of long-term potentiation (LTP) - a cellular process that underlies learning and memory $[3,52]$. There is evidence that the suppressive action of A $\beta$ on LTP in both CA1 and dentate gyrus operates via a NMDA receptorindependent pathway that involves cholinergic terminals in the hippocampus. Of some interest, HupA $(1.0 \mu M)$ was found to enhance LTP, while a much lower dose $(0.1 \mu M)$ largely blocked the suppressive effects of $\mathrm{A} \beta$ on LTP induction $[8,80]$.
Neuronal cell death caused by overstimulation of glutamate receptors has been proposed as the final common pathway for a variety of neurodegenerative diseases including AD. The ability of HupA to attenuate glutamatemediated neurotoxicity may be one additional reason for considering this agent as a potential therapeutic for dementia and as a means of slowing or halting the pathogenesis of AD at an early stage [20].

\section{Acknowledgements}

This work was supported in part by the grants from Ministry of Science and Technology of China (G199805110, G1998051115) and National Natural Science Foundation of China (39170860, 39770846, 3001161954, 30123005 and 30271494). The authors are grateful to Professor Stephen W. Brimijoin (Mayo Clinic, USA) for English revision on the manuscript.

\section{References}

1 Bartus RT, Dean RL 3rd, Beer B, Lippa AS: The cholinergic hypothesis of geriatric memory dysfunction. Science 1982;217:408-414.

2 Behl C, Moosmann B: Antioxidant neuroprotection in Alzheimer's disease as preventive and therapeutic approach. Free Radic Biol Med 2002;33:182-191.

-3 Bliss TVP, Collingridge GL: A synaptic model of memory: long-term potentiation in the hippocampus. Nature 1993;361:31-39.

4 Bon S, Vigny M, Massoulie J: Asymmetric and globular forms of AChE in mammals and birds. Proc Natl Acad Sci USA 1979;76:2540-2550.

$\checkmark 5$ Bossy-Wetzel E, Newmeyer DD, Green DR: Mitochondrial cytochrome c release in apoptosis occurs upstream of DEVD-specific caspase activation and independently of mitochondrial transmembrane depolarization. EMBO J 1998; 17:37-49.

6 Brimijoin S: Molecular forms of acetylcholinesterase in brain, nerve and muscle: nature, localization and dynamics. Prog Neurobiol 1983; 21:291-322.

7 Butterfield DA, Howard B, Yatin S, Koppal T, Drake J, Hensley K, Aksenov M, Subramaniam R, Varadarajan S, Harris-White ME, Pedigo NW Jr, Carney JM: Elevated oxidative stress in models of normal brain aging and Alzheimer's disease. Life Sci 1999;65:1883-1892.

$\checkmark 8$ Chen QS, Kagan BL, Hirakura Y, Xie CW: Impairment of hippocampal long-term potentiation by Alzheimer amyloid beta-peptides. J Neurosci Res 2000;60:65-72.

$\checkmark 9$ Cheng DH, Tang XC: Comparative studies of huperzine A, E2020, and tacrine on behavior and cholinesterase activities. Pharmacol Biochem Behav 1998;60:377-386.
10 Choi DW: Calcium-mediated neurotoxicity: Relationship to specific channel types and role in ischemic damage. Trends Neurosci 1988;11: 465-469.

11 Choi DW: Calcium and excitotoxic neuronal injury. Ann NY Acad Sci 1994;747:162-171.

12 Choi DW: Calcium: still center-stage in hypoxic-ischemic neuronal death. Trends Neurosci 1995; 18:58-60.

13 DiFiglia M: Excitotoxic injury of the neostriatum: A model for Huntington's disease. Trends Neurosci 1990;13:286-289.

14 Dirnagl U, Iadecola C, Moskowitz MA: Pathobiology of ischaemic stroke: An integrated view. Trends Neurosci 1999;22:391-397.

15 Esch FS, Keim PS, Beattie EC, Blacher RW, Culwell AR, Oltersdorf T, McClure D, Ward PJ: Cleavage of amyloid beta-peptide during constitutive processing of its precursor. Science 1990:248:1122-1124.

16 Gao Y, Tang XC, Guan LC, Kuang PZ: Huperzine A reverses scopolamine- and muscimolinduced memory deficits in chick. Acta Pharmacol Sin 2000;21:1169-1173.

17 Gasparini L, Racchi M, Binetti G, Trabucchi M, Solerte SB, Alkon D, Etcheberrigaray R, Gibson G, Blass J, Paoletti R, Govoni S: Peripheral markers in testing pathophysiological hypotheses and diagnosing Alzheimer's disease. FASEB J 1998;12:17-34

18 Giacobini E, Mori F, Lai CC: The effect of cholinesterase inhibitors on the secretion of APPs from rat brain cortex. Ann NY Acad Sci 1996; 777:393-398.

19 Gilgun-Sherki Y, Melamed E, Offen D: Antioxidant treatment in Alzheimer's disease: Current state. J Mol Neurosci 2003;21:1-12
20 Gordon RK, Nigam SV, Weitz JA, Dave JR, Doctor BP, Ved HS: The NMDA receptor ion channel: A site for binding of huperzine A. J Appl Toxicol 2001;21(suppl 1):S47-S51.

21 Graham SH, Chen J: Programmed cell death in cerebral ischemia. J Cereb Blood Flow Metab 2001;21:99-109.

-22 Grassi J, Vigny M, Massoulie J: Molecular forms of acetylcholinesterase in bovine caudate nucleus and superior cervical ganglion: Solubility properties and hydrophobic character. J Neurochem 1982;387:457-469.

23 Guan LC, Chen SS, Cui QG, Lu WH, Tang XC: The effects of huperzine A on behavior and ECoG in animals. Acta Psychol Sin 1991; 23:404-411.

24 Haass C, Selkoe DJ: Cellular processing of beta-amyloid precursor protein and the genesis of amyloid-beta peptide. Cell 1993;75:10391042.

25 Halestrap AP, McStay GP, Clarke SJ: The permeability transition pore complex: Another view. Biochimie 2000;84:153-166.

-26 Hossmann KA: Glutamate-mediated injury in focal cerebral ischemia: The excitotoxin hypothesis revised. Brain Pathol 1994;4:23-36.

27 Hynd MR, Scott HL, Dodd PR: Glutamatemediated excitotoxicity and neurodegeneration in Alzheimer's disease. Neurochem Int 2004; 45:583-595.

28 Kim JS, He L, Lemasters JJ: Mitochondrial permeability transition: A common pathway to necrosis and apoptosis. Biochem Biophys Res Commun 2003;304:463-470

29 Ko LJ, Prives C: p53: Puzzle and paradigm. Genes Dev 1996;10:1054-1072. 
30 Eckert A, Marques CA, Keil U, Schussel K, 46 Racchi M, Govoni S: Rationalizing a pharmaMuller WE: Increased apoptotic cell death in sporadic and genetic Alzheimer's disease. Ann NY Acad Sci 2003;1010:604-609.

31 Lee JM, Zipfel GJ, Choi DW: The changing landscape of ischaemic brain injury mechanisms. Nature 1999;399(suppl):A7-A14.

32 Li HN, Min QY: Huperzine A improved the cognition of vascular dementia: A report of 30 patients in therapeutics. Xian Dai Kang Fu 2001;5:59

-33 Li Y, Hu GY: Huperzine A inhibits the sustained potassium current in rat dissociated hippocampal neurons. Neurosci Lett 2002;329: 153-156.

-34 Liang YQ, Tang XC: Comparative effects of huperzine $\mathrm{A}$, donepezil and rivastigmine on cortical acetylcholine level and acetylcholinesterase activity in rats. Neurosci Lett 2004;361: 56-59.

-35 Lipton SA, Rosenberg PA: Excitatory amino acids as a final common pathway for neurologic disorders. N Engl J Med 1994;330:613-622.

-36 Liu J, Zhang HY, Tang XC, Wang B, He XC, Bai DL: Effects of synthetic (-)-huperzine A on cholinesterase activities and mouse water maze performance. Acta Pharmacol Sin 1998;19: 413-416.

-37 Lu WH, Shou J, Tang XC: Improving effect of huperzine A on discrimination performance in aged rats and adult rats with experimental cognitive impairment. Acta Pharmacol Sin 1988; 9:11-15.

-38 Ma YX, Zhu Y, Gu YD, Yu ZY, Yu SM, Ye YZ: Double-blind trial of huperzine-A (HUP) on cognitive deterioration in 314 cases of benign senescent forgetfulness, vascular dementia, and Alzheimer's disease. Ann NY Acad Sci 1998;854:506-507.

39 Pi X, Liu Y, Jiang ZY, Hu XQ, Zhu GZ: Clinical observations on treatment of light and moderate vascular dementia with meclofenoxate plus huperzine A. Shanghai Med Pharmaceut J 2004;255:409-411.

40 Markesbery WR: Oxidative stress hypothesis in Alzheimer's disease. Free Rad Biol Med 1997;23:134-147.

$\checkmark 41$ Massoulie J, Bon S: The molecular forms of cholinesterase and acetylcholinesterase in vertebrate. Annu Rev Neurosci 1982;5:57-106.

42 Mori F, Lai CC, Fusi F, Giacobini E: Cholinesterase inhibitors increase secretion of APPs in rat brain cortex. NeuroReport 1995;6:633636.

43 Nitsch RM, Slack BE, Wurtman RJ, Growdon $\mathrm{J}$ : Release of Alzheimer amyloid precursor derivative stimulated by activation of muscarinic acetylcholine receptors. Science 1992;258: 304-307.

44 Ou LY, Tang XC, Cai JX: Effect of huperzine A on working memory in reserpine- or yohimbine-treated monkeys. Eur J Pharmacol 2001; 433:151-156.

-45 Perry EK, Tomlinson VE, Blessed G, Bergman K, Gibson PH, Perry RH: Correlation of cholinergic abnormalities with senile plaques and mental scores. Br Med J 1978;ii:1457-1459. cological intervention on the amyloid precursor protein metabolism. Trends Pharmacol Sci 1999;20:418-423.

47 Rossner S, Ueberham U, Schliebs R, PerezPolo JR, Bigl V: The regulation of amyloid precursor protein metabolism by cholinergic mechanisms and neurotrophin receptor signaling. Prog Neurobiol 1998;56:541-569.

48 Selkoe DJ, Abraham CR, Podlisny MB, Duffy LK: Isolation of low-molecular-weight proteins form amyloid plaque fibers in Alzheimer's disease. J Neurochem 1986;46:1820-1834.

49 Shang YZ, Ye JW, Tang XC: Improving effects of huperzine A on abnormal lipid peroxidation and superoxide dismutase in aged rats. Acta Pharmacol Sin 1999;20:824-828.

50 Simon RP, Swan JH, Griffiths T, Meldrum BS: Blockade of N-methyl-aspartate receptors may protect against ischemic damage in the brain. Science 1984;226:850-852.

51 Smale G, Nichols NR, Brady DR, Finch CE, Horton WE Jr: Evidence for apoptotic cell death in Alzheimer's disease. Exp Neurol 1995; 133:225-230.

52 Sucher NJ, Awobuluyi M, Choi YB, Lipton SA NMDA receptors: From genes to channels. Trends Pharmacol Sci 1996;17:348-355.

53 Szalai G, Krishnamurthy R, Hajnoczky G: Apoptosis driven by IP(3)-linked mitochondrial calcium signals. EMBO J 1999;18:6349_ 6361.

54 Tang XC, Han YF, Chen XP, Zhu XD: Effects of huperzine A on learning and retrieval process of discrimination performance in rats. Acta Pharmacol Sin 1986; 7:507-511.

55 Tang XC, De Sarno P, Sugaya K, Giacobini E: Effect of huperzine A, a new cholinesterase inhibitor, on the central cholinergic system of the rat. J Neurosci Res 1989;24:276-285.

56 Tang XC, He XC, Bai DL: Huperzine A: A novel acetylcholinesterase inhibitor. Drug Future 1999;24:647-663.

$>57$ Turski L, Huth A, Sheardown M, McDonald F, Neuhaus R, Schneider HH, Dirnagl U, Wiegand F, Jacobsen P, Ottow E: ZK200775: A phosphonate quinoxalinedione AMPA antagonist for neuroprotection in stroke and trauma. Proc Natl Acad Sci USA 1998;95:1096010965.

58 Ved HS, Koening ML, Dave JR, Doctor BP: Huperzine A, a potential therapeutic agent for dementia, reduces neuronal cell death caused by glutamate. NeuroReport 1997;8:963-968.

59 Vincent GP, Rumennik L, Cumin R, Martin J, Sepinwall J: The effects of huperzine A, an acetylcholinesterase inhibitor, on the enhancement of memory in mice, rats and monkeys. Neurosci Abstr 1987;13:844.

60 Wang H, Tang XC: Anticholinesterase effects of huperzine A, E2020, and tacrine in rats. Acta Pharmacol Sin 1998;19:27-30.

61 Wang LM, Han YF, Tang XC: Huperzine A improves cognitive deficits caused by chronic cerebral hypoperfusion in rats. Eur J Pharmocol 2000;398:65-72.
62 Wang LS, Zhou J, Shao XM, Tang XC: Huperzine $\mathrm{A}$ attenuates cognitive deficits and brain injury in neonatal rats after hypoxia-ischemia. Brain Res 2002;949:162-170.

63 Wang R, Xiao XQ, Tang XC: Huperzine A attenuates hydrogen peroxide-induced apoptosis by regulation expression of apoptosis-related genes in rat PC12 cells. NeuroReport 2001; 12:2629-2634

64 Wang R, Zhang HY, Tang XC: Huperzine A attenuates cognitive dysfunction and neuronal degeneration caused by beta-amyloid protein(1-40) in rat. Eur J Pharmacol 2001;421:149156.

65 Wang T, Tang XC: Reversal of scopolamineinduced deficits in radial maze performance by (-)-huperzine A: Comparison with E2020 and tacrine. Eur J Pharmacol 1998;349:137-142.

66 Wang XD, Zhang JM, Yang HH, Hu GY: Modulation of NMDA receptor by huperzine A in rat cerebral cortex. Acta Pharmacol Sin 1999;20:31-35.

67 Wang YE, Yue DX, Tang XC: Anticholinesterase activity of huperzine A. Acta Pharmacol Sin 1986;7:110-113.

68 Xiao XQ, Yang JW, Tang XC: Huperzine A protects rat pheochromocytoma cells against hydrogen peroxide-induced injury. Neurosci Lett 1999;275:73-76.

69 Xiao XQ, Wang R, Han YF and Tang XC: Protective effects of huperzine A on $\beta$-amyloid2525 induced oxidative injury in rat pheochromocytoma cells. Neurosci Lett 2000;286:155158

70 Xiao XQ, Wang R, Tang XC: Huperzine A and tacrine attenuate $\beta$-amyloid peptide induced oxidative injury. J Neurosci Res 2000;61:564569

71 Xiao XQ, Zhang HY, Tang XC: Huperzine A attenuates amyloid $\beta$-peptide fragment 25-35induced apoptosis in rat cortical neurons via inhibiting reactive oxygen species formation and caspase-3 activation. J Neurosci Res 2002; 67:30-36.

72 Xiong ZQ, Tang XC: Effect of huperzine A, a novel acetylcholinesterase inhibitor, on radial maze performance in rats. Pharmacol Biochem Behav 1995;51:415-419.

73 Xiong ZQ, Han YF, Tang XC: Huperzine A ameliorates the spatial working memory impairments induced by AF64A. NeuroReport 1995;6:2221-2224.

74 Xiong ZQ, Cheng DH, Tang XC: Effects of huperzine A on nucleus basalis magnocellularis lesion-induced spatial working memory deficit. Acta Pharmacol Sin 1998;19:128-132.

$75 \mathrm{Xu}$ SS, Gao ZX, Weng Z, Du ZM, Xu WA, Yang JS, Zhang ML, Tong ZH, Fang YS, Chai XS, Li SL: Efficacy of tablet huperzine A on memory, cognition, and behavior in Alzheimer's disease. Acta Pharmacol Sin 1995;16: 391-395.

76 Xu SS, Xie HB, Du ZW, Tong ZH, Shi QC, Lu KM, Li SL, Lin B: Efficacy of tablet huperzine A on memory and cognition in patients with benign senescent forgetfulness. Chin J Clin Pharmacol Ther 1997;2:1-4. 
77 Xu SS, Cai ZY, Qu ZW, Yang RM, Cai YL, Wang GQ: Huperzine A in capsules and tablets for treating patients with Alzheimer's disease. Acta Pharmacol Sin 1999;20:486-490.

-78 Ye JW, Cai JX, Wang LM, Tang XC: Improving effects of huperzine A on spatial working memory in aged monkeys and young adult monkeys with experimental cognitive impairment. J Pharmacol Exp Ther 1999;288:814819.

79 Ye JW, Shang YZ, Wang ZM, Tang XC: Huperzine A ameliorates the impaired memory of aged rat in the Morris water maze performance. Acta Pharmacol Sin 2000;21:65-69.

80 Ye L, Qiao JT: Suppressive action produced by beta-amyloid peptide fragment 31-35 on longterm potentiation in rat hippocampus is $\mathrm{N}$ methyl- $D$-aspartate receptor-independent: it's offset by (-)huperzine A. Neurosci Lett 1999; 275:187-190.

-81 Yu SP, Farhangrazi ZS, Ying HS, Yeh CH, Choi DW: Enhancement of outward potassium current may participate in beta-amyloid peptide-induced cortical neuronal death. Neurobiol Dis 1998;5(2):81-88.

82 Yuan J, Yankner BA: Apoptosis in the nervous system. Nature 2000;407:802-809.

83 Zamzami N, Kroemer G: The mitochondrion in apoptosis: How Pandora's box opens. Nature Reviews in Molecular and Cellular Biology 2001;21:67-71.

84 Zhang CL, Wang GZ: Effects of huperzine A tablet on memory. New Drugs Clin Remed 1990;9:339-341.

85 Zhang HY, Brimijoin S, Tang XC: Apoptosis induced by $\beta$-amyloid $25-35$ in acetylcholinesterase-overexpressing neuroblastoma cells. Acta Pharmacol Sin 2003;24:853-858.
86 Zhang HY, Liang YQ, Tang XC, He XC, Bai DL: Stereoselectivities of enantiomers of huperzine A in protection against amyloid 25-35induced injury in PC12 and NG108-15 cells and cholinesterase inhibition in mice. Neurosci Lett 2002;317:143-146.

87 Zhang HY, Tang XC: Huperzine A attenuates the neurotoxic effect of staurosporine in primary rat cortical neurons. Neurosci Lett 2003; 340:91-94.

88 Zhang HY, Yan H, Tang XC: Huperzine A enhances the level of secretory amyloid precursor protein and protein kinase C- $\alpha$ in intracerebroventricular $\beta$-amyloid-(1-40) infused rats and human embryonic kidney 293 Swedish mutant cells. Neurosci Lett 2004;360:21-24.

89 Zhang JM, Hu GY: Huperzine A, a nootropic alkaloid, inhibits N-methyl- $D$-aspartate-induced current in rat dissociated hippocampal neurons. Neuroscience 2001;105:663-669.

90 Zhang RW, Tang XC, Han YY, Sang GW, Zhang YD, Ma YX, Zhang CL, Yang RM: Drug evaluation of huperzine A in the treatment of senile memory disorders. Acta Pharmacol Sin 1991;12:250-252.

91 Zhang YH, Chen XQ, Yang HH, Jin GY, Bai DL, Hu GY: Similar potency of the enantiomers of huperzine $\mathrm{A}$ in inhibition of $[(3) \mathrm{H}] \mathrm{di}-$ zocilpine (MK-801) binding in rat cerebral cortex. Neurosci Lett 2000;295:116-118.
92 Zhang YH, Zhao XY, Chen XQ, Wang Y, Yang HH, Hu GY: Spermidine antagonizes the inhibitory effect of huperzine $\mathrm{A}$ on $\left[{ }^{3} \mathrm{H}\right] \mathrm{di}-$ zocilpine (MK-801) binding in synaptic membrane of rat cerebral cortex. Neurosci Lett 2002;319:107-110.

93 Zhao Q, Tang XC: Effects of huperzine A on acetylcolinesterase isoforms in vitro: Comparison with tacrine, donepezil, rivastigmine and physostigmine. Eur J Pharmacol 2002; 455:101-107.

94 Zhou J, Fu Y, Tang XC: Huperzine A protects rat pheochromocytoma cells against oxygen-glucose deprivation. NeuroReport 2001; 12:2073-2077.

-95 Zhou J, Fu Y, Tang XC: Huperzine A and donepezil protect rat pheochromocytoma cells against oxygen-glucose deprivation. Neurosci Lett 2001;306:53-56.

96 Zhou J, Zhang HY, Tang XC: Huperzine A attenuates cognitive deficits and hippocampal neuronal damage after transient global ischemia in gerbils. Neurosci Lett 2001;313: 137-140.

$\checkmark 97$ Zhou J, Tang XC: Huperzine A attenuates apoptosis and mitochondria-dependent caspase-3 in rat cortical neurons. FEBS Lett 2002;526:21-25.

98 Zhu XD, Tang XC: Facilitatory effects of huperzine $\mathrm{A}$ and $\mathrm{B}$ on learning and memory of spatial discrimination in mice. Acta Pharmacol Sin 1987;22:812-817.

$\checkmark 99$ Zhu XD, Tang XC: Improvement of impaired memory in mice by huperzine $\mathrm{A}$ and huperzine B. Acta Pharmacol Sin 1988;9: 492-497.

100 Zhu XD, Giacobini E: Second generation cholinesterase inhibitors: Effect of $(L)$-huperzine A on cortical biogenic amines. J Neurosci Res 1995;41:828-835. 